\title{
Hand-Rearing of Twin Gray Seals (Halichoerus grypus) from Birth to Weaning*
}

\author{
Stephen Spotte ${ }^{1}$ and Paul E. Stake ${ }^{2}$ \\ ${ }^{1}$ Sea Research Foundation, Inc., Mystic Marinelife Aquarium, Mystic, Connecticut 06355, USA \\ 2 Department of Nutritional Sciences, University of Connecticut, Storrs, Connecticut 06268, USA
}

\begin{abstract}
Captive-born twin gray seals Halichoerus grypus were hand-reared to weaning at $30 \mathrm{~d}$ postpartum. Two artificial formulas were used, starting on Days 1 and 11, respectively. Supplemental force-feeding with whole fish started on Day 9. The pups were trained to bottle-feed from the beginning, and regulated their own intake of formula. No suckling pattern was evident. Proximate analyses of the formulas and raw fish were performed, and the total daily energy requirements were calculated. Regression analysis of daily change in body weight on kilocaloric intake per metabolic body weight ( $\mathrm{kcal} \mathrm{kg}^{-.75}$ ) yielded the equation

$$
Y_{(\Delta \text { body } w t, k g)}=-0.464+0.00128 X\left(\mathrm{kcal} \mathrm{kg}^{-.75}\right)
$$

in which $r^{2}=0.49$. Maintenance gross energy requirement $(Y=0)$ was $362 \mathrm{kcal} \mathrm{kg}^{-1}$ of metabolic weight, indicating a minimum need of $2775-3185 \mathrm{kcal} \mathrm{d}^{-1}$. Total kilocalories consumed each day showed a bell-shaped pattern, being highest in the third week. Diarrhea was mild but chronic, which probably resulted in overestimation of the maintenance gross energy requirement. The rearing formulas were inadequate to promote normal growth, despite the addition of fish, and incremental weight gain was considerably less than in wild pups. Results indicate that environmental pressures may be more limiting than composition of the diet.
\end{abstract}

\section{INTRODUCTION}

Pinnipeds (true seals, fur seals, sea lions, and walruses) exist at the apex of oceanic food chains, yet their significance in marine ecosystems is poorly understood. Since the classic paper by Lindemann (1942) it has become accepted practice to view ecosystems in terms of energy flow. By monitoring the transfer of energy from one trophic level to another it is possible to assess the role of a population and estimate its impact. The principles of ecological energetics are useful adjuncts in wildlife biology. In their study of neonatal growth of northwest Atlantic harp seals (Phoca groenlandicus), Stewart and Lavigne (1980) wrote: 'For exploited populations in particular, productivity, or rate of biomass (energy) must be known in order to formulate appropriate management programs.' Any such analysis must ultimately consider the

\footnotetext{
- Contribution No. 30, Sea Research Foundation, Inc. Supported in part by, and Scientific Contribution No. 905 of, the Storrs Agricultural Experiment Station
}

physiological energetics of individual animals. As Stewart and Lavigne pointed out, growth of the neonate is a function of energy stored in the milk, which in turn represents a significant percentage of the annual production energy of adult females.

The captive rearing of marine organisms is an indispensible tool of marine ecologists. In the case of pinnipeds, efforts to date have not always led to reproducible techniques. However, quantitative descriptions of rearing methods are necessary preludes to more exacting studies, including those involving energetics. One serious obstacle has been the lack of a suitable substitute for seal milk, one that promotes normal growth. The availability of such a formulation would greatly augment research in pinniped energetics. The birth, and subsequent rejection by the mother, of twin gray seal (Halichoerus grypus) pups at Mystic Marinelife Aquarium (Mystic, Connecticut, USA) provided an opportunity to hand-rear the animals to weaning and record their progress. In doing so, we gained a rudimentary understanding of their energy requirements. 


\section{METHODS}

Parturition. The gray seals at Mystic Marinelife Aquarium came from the Canadian population. The pups described in this report were dizygotic twins born to a primiparous female that had conceived in the exhibit. Pregnancy had been confirmed in October 1980 using an ultrasound scanner *. Only one fetus was seen at that time, and the birth of the second pup was unexpected. The female was moved indoors on the evening of 28 December 1980 and placed in a small enclosure that includes a pool. The pool was drained at $1630 \mathrm{~h}$ the next day and the animal was left lying on the bottom. At $1730 \mathrm{~h}$ dilation of the vagina was observed. Ordinarily, gray seal pups are delivered rapidly (Burton et al., 1975). When parturition still had not occurred by $2033 \mathrm{~h}, 60$ I.U. $\left(3 \mathrm{~cm}^{3}\right)$ of oxytocin * were administered intramuscularly to induce labor. The dosage had no apparent effect, and a second injection of 80 I.U. $\left(4 \mathrm{~cm}^{3}\right)$ was administered $10 \mathrm{~min}$ later. The first pup (female) was born at $2139 \mathrm{~h}$ and parturition took $35 \mathrm{~min}$. The second pup (male) was born at $0610 \mathrm{~h}$ the next day (30 December), 10 min after labor began. Weights and standard lengths (nose to tail) were taken at $0945 \mathrm{~h}$. The female was $94 \mathrm{~cm}$ and $14.7 \mathrm{~kg}$; the male $87.6 \mathrm{~cm}$ and $13.6 \mathrm{~kg}$. The weights of both pups were within the normal range for newborn gray seals from the Canadian population (Mansfield, 1977); no values for standard length are available. Some weight loss may have occurred, because neither animal had suckled.

I $n$ i t i a l f e e d ing. By noon on 30 December (Day 1) it was evident that the female had rejected both pups. At $1220 \mathrm{~h}$ they subsequently were force-fed $60 \mathrm{ml}$ of artificial milk (Formula A, Table 1) through a stomach tube. The intubation apparatus consisted of $60 \mathrm{~cm}$ of clear polyethylene tubing $(0.79 \mathrm{~cm}$ outside diameter, $0.16 \mathrm{~cm}$ wall thickness) ${ }^{*}{ }^{\prime}$ and a $60-\mathrm{ml}$ syringe. The end of the tubing was flamed to round off any rough edges that might have damaged the esophageal mucosa. The tubing was inserted in the esophagus to a depth equal to the distance from the tip of the nose to the position of the foreflippers, or $\sim 38$ $\mathrm{cm}$. Intubation was repeated at $1335 \mathrm{~h}(150 \mathrm{ml})$ and $1952 \mathrm{~h}(90 \mathrm{ml})$. Bottle-training commenced at $1753 \mathrm{~h}$ on Day 1, using standard bottles and nipples manufactured for human babies and filled with Formula $A$. The nipples were inserted in holes in four different mate-

\footnotetext{
- Toshiba SAL-20 Linear Array Real-Time Ultrasound Scanner, Toshiba Medical Systems, Carson, Calif. 70945, USA

- Oxytocin (20 I.U. $\mathrm{cm}^{-3}$ ), Spencer Mead, Inc., Valley Stream, N.Y 11582, USA

-. Nalgene 800 Nontoxic Autoclavable Lab/Food Tubing, Sybron/Nalge, Rochester, N.Y 14602, USA
}

rials in succession to determine which provided the best tactile stimulus to induce suckling.

Formula preparation. Formulas $A$ and $B$ were prepared by the same method. All ingredients except whipping cream were mixed to a uniform homogenate in a commercial blender, then strained through a fine-mesh net to remove pieces of bones and scales that clogged the nipples. Whipping cream was stirred in by hand and the mixture was diluted to volume (3 1) with tap water. Each batch was transferred to a plastic pail, which was floated in a larger pail of hot water to keep the temperature at $\sim 30^{\circ} \mathrm{C}$. Material not used after $4 \mathrm{~h}$ was discarded.

Table 1. Ingredients in Formulas A and B

\begin{tabular}{|c|c|c|}
\hline Ingredients & Formula & Vol or wt \\
\hline${ }^{1}$ Amino acid mix & $A, B$ & $250 \mathrm{ml}$ \\
\hline${ }^{2}$ Corn syrup & A, B & $500 \mathrm{ml}$ \\
\hline Headless Atlantic herring & A, B & $1.3 \mathrm{~kg}$ \\
\hline${ }^{3}$ Thiamine hydrochloride & $A, B$ & $200 \mathrm{mg}$ \\
\hline${ }^{4}$ Tocopherol & $A, B$ & $200 \mathrm{mg}$ \\
\hline${ }^{5}$ Heavy whipping cream & A, B & $1.5 \mathrm{l}$ \\
\hline${ }^{6}$ Casein (vitamin-free) & B & $150 \mathrm{~g}$ \\
\hline${ }^{7}$ Safflower oil & B & $350 \mathrm{ml}$ \\
\hline${ }^{8}$ Lecithin & B & $10 \mathrm{~g}$ \\
\hline${ }^{9}$ Tap water & A, B & $\sim 1.01$ \\
\hline \multirow{2}{*}{\multicolumn{3}{|c|}{$\begin{array}{l}\text { 'AA } 1000 \text {, Beecham Laboratories, Bristol, TN } 37620 \text {, USA. } \\
\text { Content per } 100 \mathrm{ml}: 1 \mathrm{~g} \text { crystalline amino acids, } 5 \mathrm{~g} \\
\text { dextrose, } 180 \mathrm{mg} \mathrm{B} \mathrm{vitamins,} 800 \mathrm{mg} \text { electrolytes } \\
{ }^{2} \text { Karo Light Corn Syrup, CPC International, Inc., } \\
\text { Englewood Cliffs, NJ 07632, USA }\end{array}$}} \\
\hline & & \\
\hline \multicolumn{3}{|c|}{$\begin{array}{l}{ }^{3} \text { Vitamin } B_{1} \text {, Chelsea Laboratories, Inc, Inwood, NY } \\
\text { 11696, USA }\end{array}$} \\
\hline \multicolumn{3}{|c|}{${ }^{4}$ Vitamin E, Solgar Co., Inc., Lynbrook, NY 11563, USA } \\
\hline \multirow{2}{*}{\multicolumn{3}{|c|}{$\begin{array}{l}{ }^{6} \text { Vitamin Free Test Casein, Teklad Test Diets, Madison, } \\
\text { WI 53713, USA } \\
{ }^{7} \text { Hollywood Pure Safflower Oil, Hollywood Health Foods, } \\
\text { Los Angeles, CA 90061, USA }\end{array}$}} \\
\hline & & \\
\hline \multicolumn{3}{|c|}{$\begin{array}{l}{ }^{8} \text { ALC Lecithin Granules, American Lecithin Co., Inc., } \\
\text { Woodside, NY 11377, USA }\end{array}$} \\
\hline${ }^{9}$ To volume $(31)$ & & \\
\hline
\end{tabular}

Later feeding. An attendant was on duty around the clock from Days 1 through 22, and formula was given on demand. From Days 23 through 29, formula was offered only between 0800 and 1630 h. Formula was withheld starting on Day 30 . The formula was supplemented with force-fed whole Atlantic herring Clupea harengus harengus starting on Day 9 (Table 2), and Formula B (Table 1) was substituted for Formula A after 1645 h on Day 11. Force-feedings of fish were conducted 3 times daily. If a pup gagged while being force-fed, that particular feeding session was stopped. Individual fish averaged $20 \mathrm{~cm}$ and $69 \mathrm{~g}$.

$D$ at a collected. Each seal was weighed daily at 
Table 2. Daily caloric intake $\mathrm{kg}^{-1}$ of body weight of artificial formula and force-fed whole fish for unweaned, twin gray seal pups during the first $29 \mathrm{~d}$ postpartum

\begin{tabular}{|c|c|c|c|c|c|c|c|c|c|c|}
\hline \multirow[t]{3}{*}{ Day } & \multicolumn{5}{|c|}{ Female } & \multicolumn{5}{|c|}{ Male } \\
\hline & \multicolumn{2}{|c|}{ Formula } & \multicolumn{2}{|c|}{ Fish } & \multirow{2}{*}{$\begin{array}{l}\text { kcal kg-1 } \\
\text { body wt }\end{array}$} & \multicolumn{2}{|c|}{ Formula } & \multicolumn{2}{|c|}{ Fish } & \multirow{2}{*}{$\begin{array}{l}\text { kcal kg-1 } \\
\text { body wt }\end{array}$} \\
\hline & $(\mathrm{ml})$ & (kcal) & $(\mathrm{kg})$ & (kcal) & & $(\mathrm{ml})$ & (kcal) & $(\mathrm{kg})$ & (kcal) & \\
\hline 1 & 480 & 1,217 & & & 88 & 300 & 761 & & & 61 \\
\hline 2 & 955 & 2,421 & & & 175 & 1,135 & 2,877 & & & 223 \\
\hline 3 & 1,195 & 3,029 & & & 220 & 1,790 & 4,538 & & & 339 \\
\hline 4 & 2,280 & 5,780 & & & 419 & 1,450 & 3.676 & & & 274 \\
\hline 5 & 2,350 & 5,957 & & & 382 & 2,050 & 5,197 & & & 363 \\
\hline 6 & 1,550 & 3,929 & & & 241 & 1,880 & 4,766 & & & 324 \\
\hline 7 & 2,190 & 5,552 & & & 345 & 1,400 & 3,549 & & & 241 \\
\hline 8 & 1.980 & 5,019 & & & 294 & 1,500 & 3,803 & & & 250 \\
\hline 9 & 1,980 & 5,019 & 0.36 & 776 & 324 & 1,660 & 4,208 & 0.36 & 776 & 320 \\
\hline 10 & 2,080 & 5,273 & 0.93 & 2,005 & 387 & 870 & 2,205 & 0.93 & 2,005 & 225 \\
\hline 11 & 2,080 & 6,376 & 1.34 & 2,889 & 483 & 1,245 & 3,817 & 1.34 & 2,889 & 394 \\
\hline 12 & 1,770 & 5,426 & 1.45 & 3,126 & 407 & 1,620 & 4,966 & 1.45 & 3,126 & 452 \\
\hline 13 & 1,480 & 4,537 & 1.92 & 4,140 & 417 & 860 & 2,636 & 1.61 & 3,471 & 341 \\
\hline 14 & 960 & 2,943 & 1.95 & 4,204 & 349 & 1,080 & 3,311 & 1.95 & 4,204 & 401 \\
\hline 15 & 935 & 2,866 & 1.90 & 4,096 & 332 & 1,190 & 3,648 & 1.90 & 4,096 & 403 \\
\hline 16 & 1,225 & 3,755 & 1.95 & 4,204 & 372 & 1,775 & 5,441 & 1.95 & 4,204 & 471 \\
\hline 17 & 2,045 & 6,269 & 2.01 & 4,334 & 465 & 2,160 & 6,622 & 2.01 & 4,334 & 512 \\
\hline 18 & 1,820 & 5,579 & 2.01 & 4,334 & 435 & 1,215 & 3,725 & 2.01 & 4,334 & 361 \\
\hline 19 & 1,955 & 5,993 & 2.01 & 4,334 & 425 & 2,590 & 7.940 & 1.94 & 4,183 & 523 \\
\hline 20 & 2,720 & 8,338 & 1.95 & 4,204 & 516 & 2,220 & 6,805 & 2.01 & 4,334 & 470 \\
\hline 21 & 1,220 & 3.740 & 2.23 & 4,808 & 339 & 2,020 & 6,192 & 2.23 & 4,808 & 437 \\
\hline 22 & 980 & 3,004 & 2.07 & 4,463 & 291 & 1,050 & 3,219 & 2.07 & 4,463 & 307 \\
\hline 23 & 650 & 1,993 & 2.45 & 5,282 & 281 & 990 & 3,035 & 2.45 & 5,282 & 345 \\
\hline 24 & 980 & 3,004 & 3.13 & 6,748 & 390 & 690 & 2,115 & 3.12 & 6,727 & 373 \\
\hline 25 & 370 & 1,134 & 3.12 & 6,727 & 312 & 600 & 1,839 & 3.12 & 6,727 & 345 \\
\hline 26 & 450 & 1,380 & 3.36 & 7,244 & 345 & 520 & 1,594 & 3.36 & 7,244 & 341 \\
\hline 27 & 140 & 429 & 3.36 & 7,244 & 294 & 280 & 858 & 3.36 & 7,244 & 313 \\
\hline 28 & 200 & 613 & 3.13 & 6,748 & 280 & 230 & 705 & 3.36 & 7,244 & 302 \\
\hline 29 & 270 & 828 & 2.46 & 5,304 & 231 & 270 & 828 & 2.46 & 5,304 & 231 \\
\hline
\end{tabular}

$1000 \mathrm{~h}$ by placing it in a wooden box suspended from a hanging scale. This information and the time of each feeding, its duration, and volume of formula or fish ingested, was recorded in a daily log. Data from suckling sessions that occurred less than 10 min apart were combined. The nature of the stools, general health, and behavior also were recorded.

Conditions. The pups were kept indoors on a sheet of plywood $(244 \times 122 \times 0.6 \mathrm{~cm})$ laid flat on a concrete floor. The overhead fluorescent lights were left on continuously; air temperature averaged $15^{\circ} \mathrm{C}$. The pups were washed and towel-dried as often as necessary to remove feces, urine, and formula from their hair.

Proximate analyses. The composition of the diet was determined as follows. Dry Matter: Duplicate samples (250 to $300 \mathrm{~g}$ each) of individual complete formulas were homogenized, shell-frozen, and lyophilized to complete dryness. Raw, whole Atlantic herring with heads removed were dried to constant weight at $48{ }^{\circ} \mathrm{C}$ in a forced-air convection oven. Percent dry matter was calculated as the weight of the remaining solids and fat, relative to the weight of the diluted, ready-to-feed formula or raw fish sample. All further analyses were performed on representative portions of the lyophilized or air-dried material. Crude Protein: Total nitrogen was determined in triplicate analyses by the Kjeldahl method (A.O.A.C., 1965). Crude protein was calculated as $\% \mathrm{~N} \times$ 6.25. Total Lipids: Complete lipid determination was performed on duplicate, homogenized samples by repeated methanol-chloroform $\left(2: 1, \mathrm{v} \mathrm{v}^{-1}\right)$ extraction, followed by rotary evaporation at $30^{\circ} \mathrm{C}$ (Kates, 1972). Ash: Duplicate samples were dry-ashed at $600^{\circ} \mathrm{C}$ for $18 \mathrm{~h}$ (A.O.A.C., 1965). Gross Energy: Total energy values of duplicate samples of dried formulas or fish were determined by adiabatic oxygen bomb calorimetry (A.O.A.C., 1965).

\section{RESULTS AND DISCUSSION}

Geraci (1977) recommended inserting the nipple of a bottle through a strip of cotton cloth or neoprene to induce pinniped pups to bottle-feed. After the second intubation, the following materials were tried: a cotton 


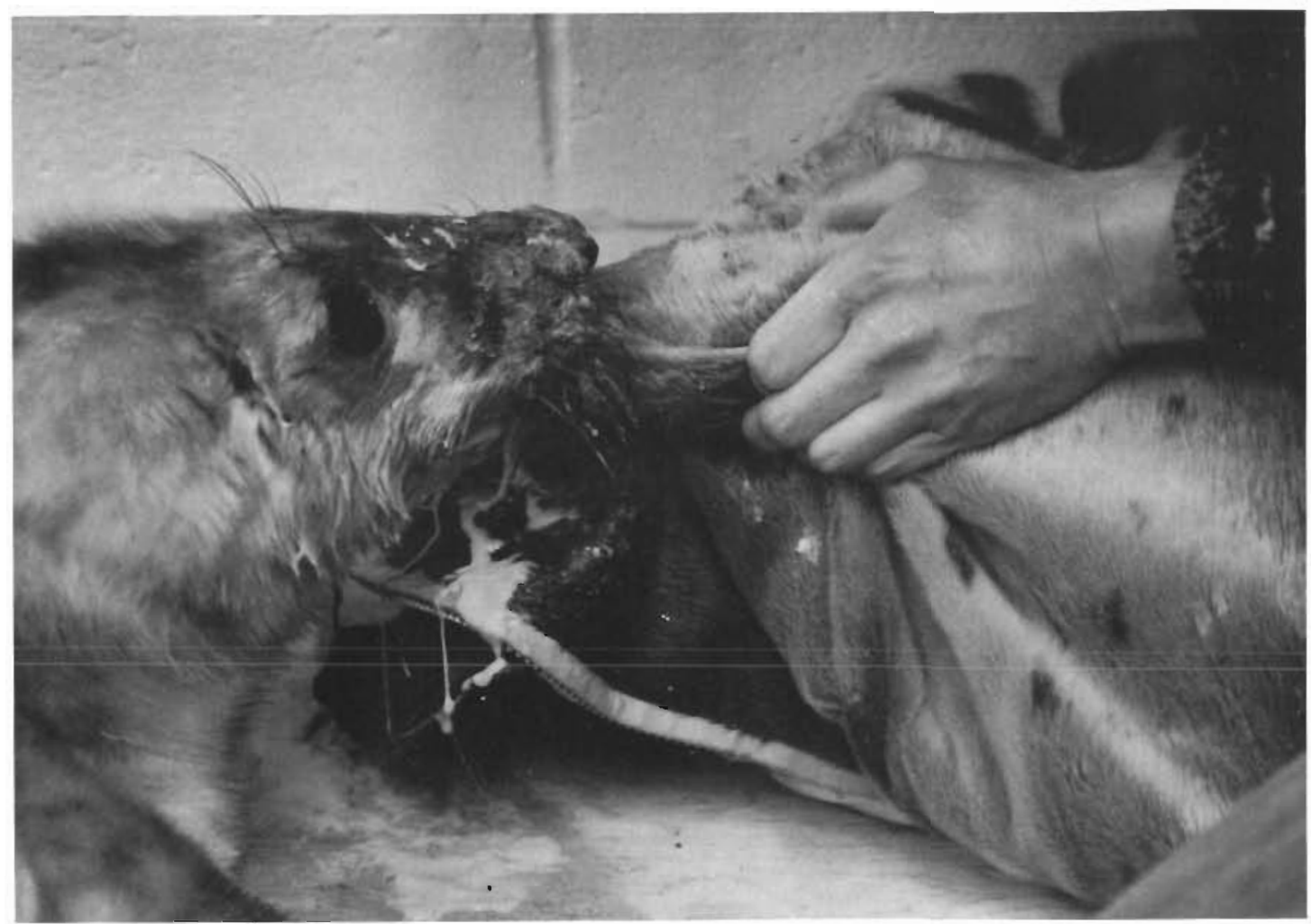

Fig. 1. Halichoerus grypus. Male pup at age $2 \mathrm{~d}$, bottle-feeding through the sealskin surrogate

shirt, a piece of neoprene from diving suit, and a strip of velour from a child's stuffed toy. None was successful. The female accepted a bottle with no such surrogate at 2234 h on Day 1 , or 282 min after the third intubation. The male refused to bottle-feed for the remainder of Day 1 and the morning of the next day (Day 2). A fourth surrogate was made from a sealskin coat. The male nuzzled the hair of the coat and suckled successfully at $1210 \mathrm{~h}$ on Day 2 (Fig. 1), the first time the sealskin surrogate was tried. Thereafter, the sealskin was used when either pup acted hungry but was unable to locate the nipple of a bottle extended to it. The female required this procedure less often than the male.

Once bottle-trained, the pups regulated their own intake of formula. Formula consumed during the first $22 \mathrm{~d}$ is shown in Figs. 2 and 3. No pattern is evident. Suckling frequency $(n)$ in each 24 -h period was variable, as was the amount of formula consumed during each suckling. From Days 23 through 29, when formula was offered only during working hours, the number of sucklings and amount of formula ingested declined. The female suckled twice on Day 24 and the male twice on Days 23 and 24; otherwise, both pups suckled only once a day. The suckling pattern of wild gray seal pups is unknown, making comparisons impossible

The total quantities of formula, force-fed fish, and kilocalories ingested each day, and the number of kilocalories ingested each $24-\mathrm{h}$ period per kilogram of body weight (based on proximate analysis), are presented in Table 2, and depicted graphically in Fig. 4. Daily caloric intake showed a general bell-shaped pattern, being highest in the third week. During the pre-weaning period, the individual daily caloric intake was 61 to $523 \mathrm{kcal} \mathrm{kg}^{-1}$ of body weight, with an average value of 341 . This is higher than the average daily energy intake of yearling gray seals $(98.7 \mathrm{kcal}$ $\mathrm{kg}^{-1}$ of body weight), as reported by Van Dyke and Ridgway (1977). However, the energy requirements of newborn mammals typically are higher than in older conspecifics (Kleiber, 1961).

Regression analysis of daily change in body weight $(\mathrm{kg})$ on kilocaloric intake per metabolic body weight (kcal $\mathrm{kg}^{-.75}$ ) yielded the following relationship

$$
Y_{\text {(A body wt. } \mathrm{kg})}=-0.464+0.00128 X\left(\mathrm{kcal} \mathrm{kg}^{-.75}\right)
$$

where $r^{2}=0.49$. Thus the maintenance gross energy requirement ( $Y=0$ ) of these 2 pups was $362 \mathrm{kcal} \mathrm{kg}^{-1}$ of metabolic body weight (Fig. 5). Considerable variation is evident in this relationship. However, moderate but consistent diarrhea may have contributed to the noticeable variation in efficiency of nutrient (energy) utilization, as measured by body weight gain. According to our data, unweaned gray seals weighing 15 to 18 $\mathrm{kg}$ would have a minimum energy requirement of 2775 to $3185 \mathrm{kcal} \mathrm{d}^{-1}$, which is high but comparable with 
Fig. 2. Halichoerus grypus. Suckling pattern of female pup and volume of formula ingested for the first 29 d postpartum; $n=$ number of suck-

lings in each 24 -h period

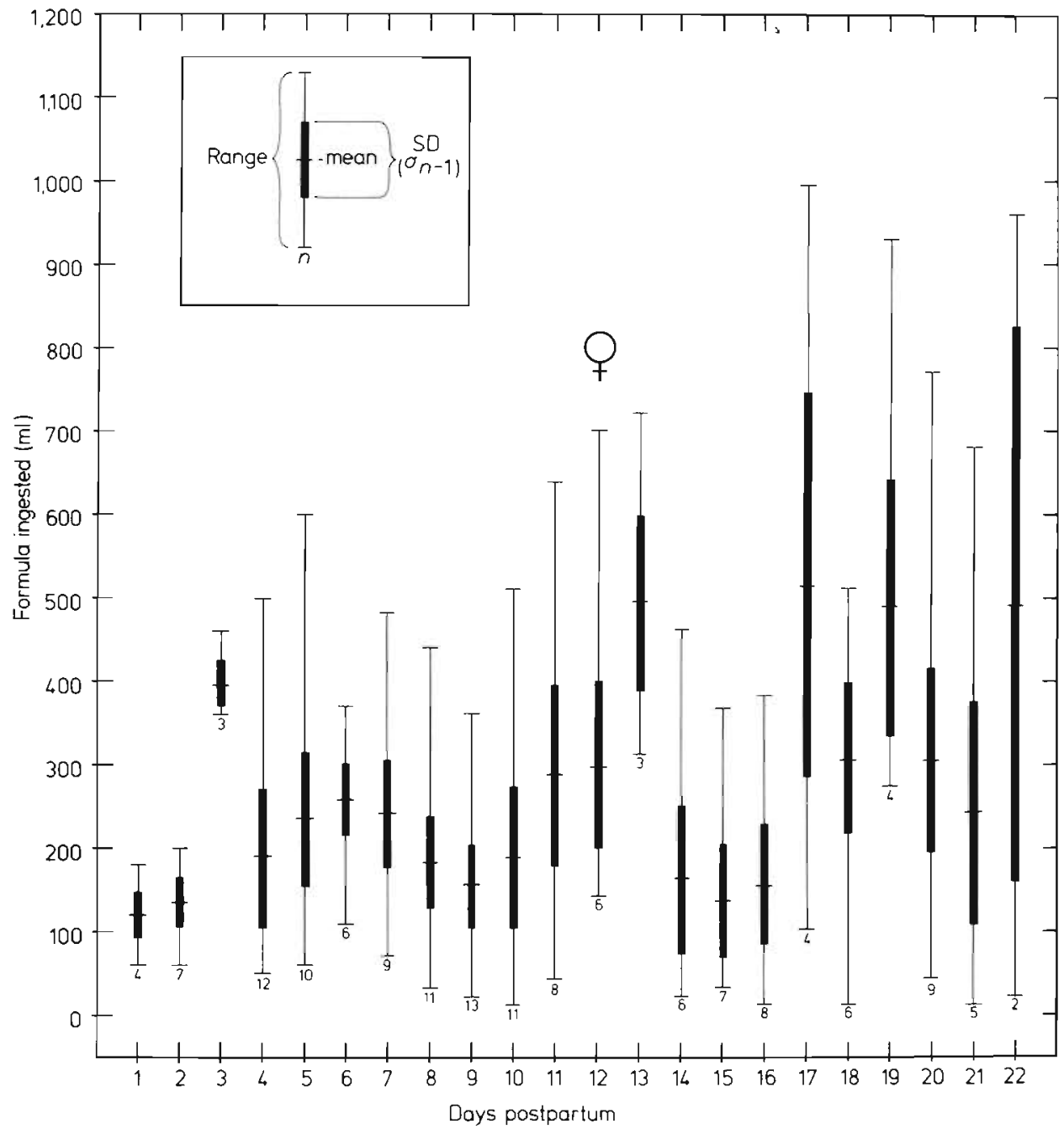

the maintenance energy estimates for other young mammals (Kleiber, 1961; Wooden et al., 1970; N.R.C., 1974, 1978).

Proximate analyses of the 2 formulas and raw herring are presented in Table 3 . The addition of casein, safflower oil, and lecithin (a fat emulsifier) to Formula $A$ to produce Formula B increased the concentration of total solids. The caloric content of Formula $B$ thus exceeded that of Formula $A$, but the percentage of fat was less. Casein and vegetable (safflower) oil are satisfactory, if marginal, protein and energy supplements for artificial formulas containing raw fish and cream.

Growth was linear, as illustrated in Fig. 6. Both pups continued to gain weight until weaning. Unweaned, wild gray seal pups grow rapidly, often doubling or tripling the birth weight during the brief suckling period. Mansfield (1977) weighed 8 pups of known age on Sable Island, Nova Scotia, at regular intervals for their first $14 \mathrm{~d}$ of life. The mean of these weights is plotted in Fig. 6. One animal grew from a birth weight of $18 \mathrm{~kg}$ to $59 \mathrm{~kg}$ during this period, or an average of
$2.9 \mathrm{~kg} \mathrm{~d}^{-1}$. Birth weight doubled and tripled in 6 and $12 \mathrm{~d}$, respectively. The average weight of the 8 pups increased from 17 to $46 \mathrm{~kg}$, or a near-tripling of birth weight in the $14-\mathrm{d}$ period. Average growth was $2.1 \mathrm{~kg}$ $\mathrm{d}^{-1}$. By comparison, our seals gained less than $0.5 \mathrm{~kg}$ $\mathrm{d}^{-1}$. At $14 \mathrm{~d}$ they weighed only 20.5 (female) and $18.8 \mathrm{~kg}$ (male), less than half the average weight of 2 week-old pups born in the wild.

The combined nutritional value in the fish and formula obviously was inferior to gray seal milk, as shown by failure of the pups to gain weight normally, and as demonstrated by proximate analysis (Table 3). Surprisingly, a complete proximate analysis of gray seal milk still has not been published. A preliminary report by Amoroso and Mathews (1951) stated only that it contains approximately $52.2 \%$ fat, $11.2 \%$ protein, $2.6 \%$ lactose, and $0.7 \%$ ash. Compared with gray seal milk, both formulas contained insufficient fat and protein, and perhaps were deficient in other constituents as well, despite the addition of fish.

The rapid growth of wild gray seal pups may be an 


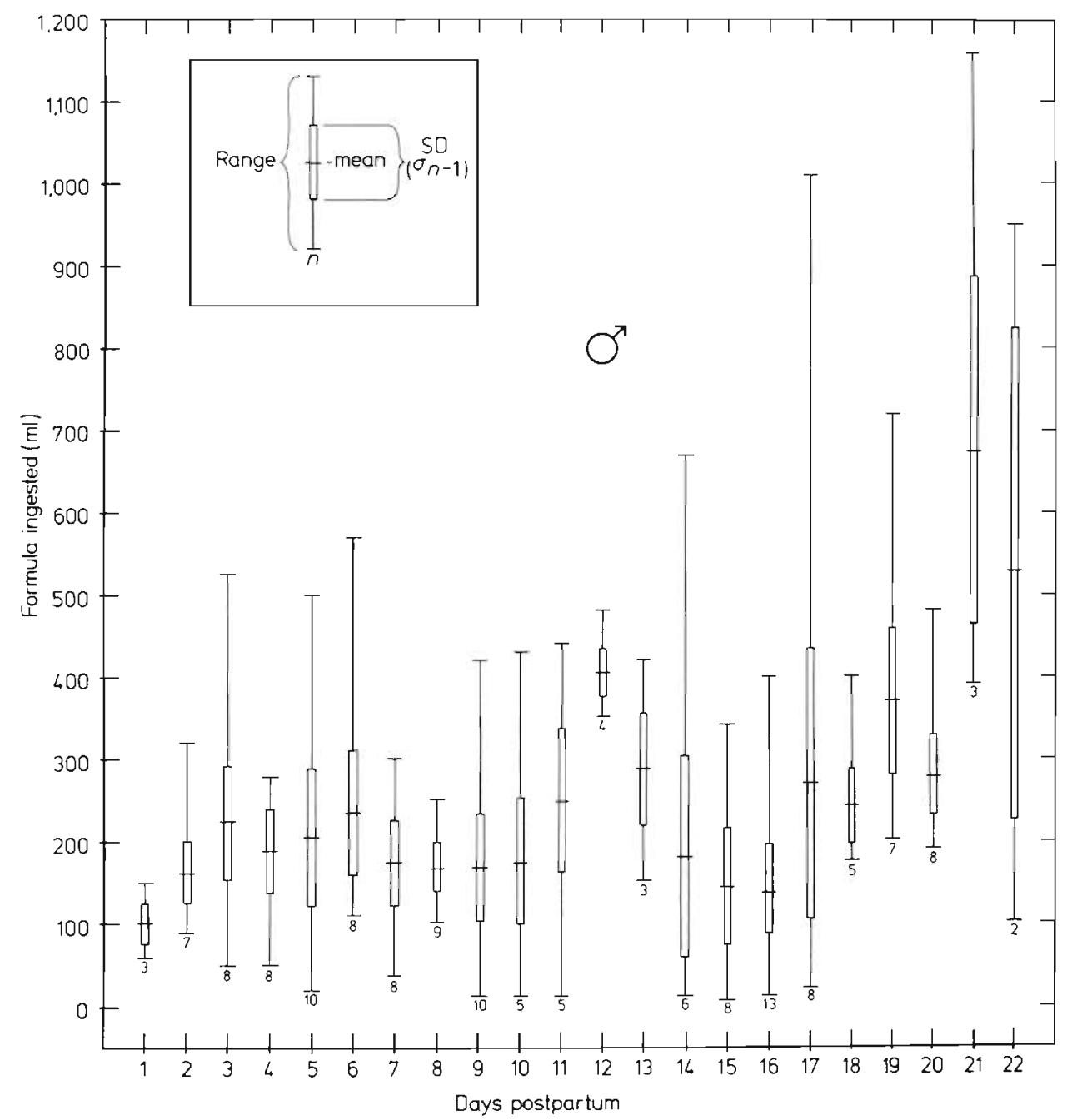

Fig. 3. Halichoerus grypus. Suckling pattern of male pup and volume of formula ingested for the first $29 \mathrm{~d}$ postpartum; $n=$ number of sucklings in each 24 - $h$ period

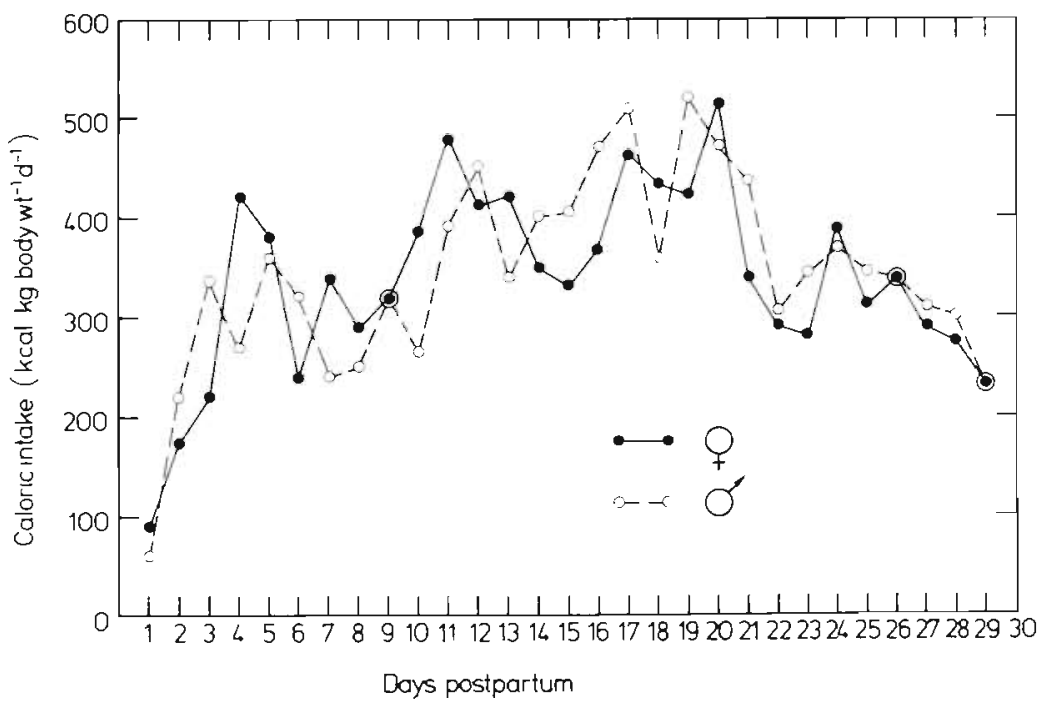

Fig. 4. Halichoerus grypus. Daily caloric intake of twin gray seal pups for the entire preweaning period of 29 d, plotted from data in Table 2 


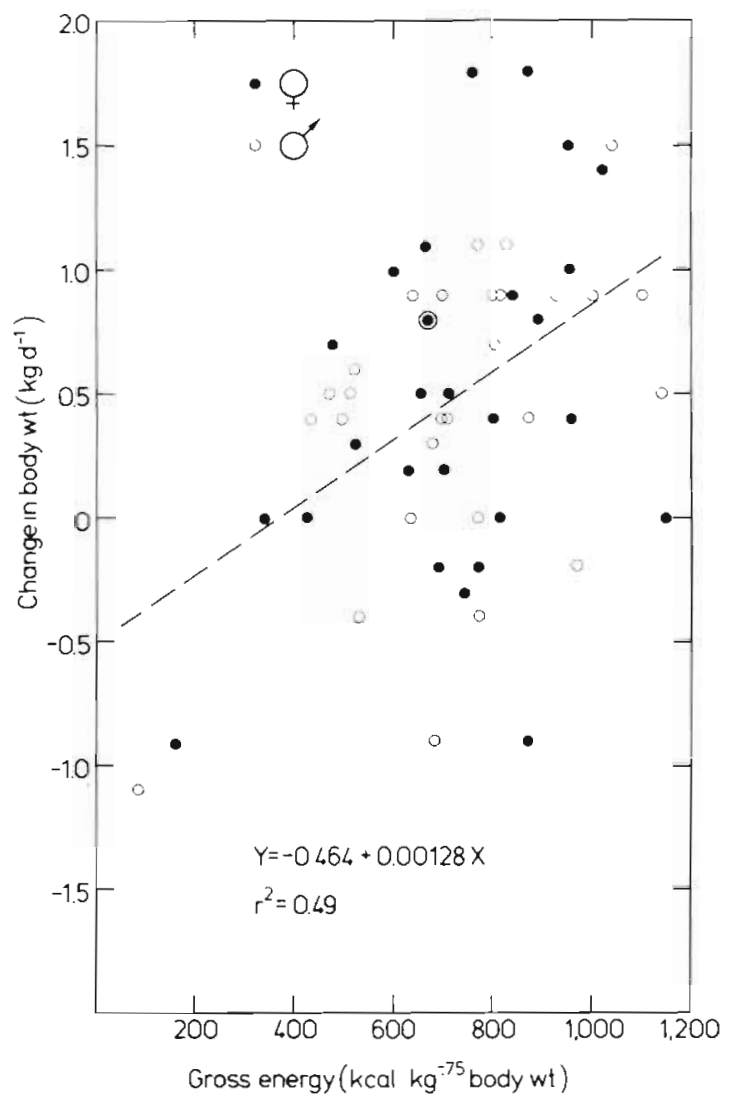

Fig. 5. Halichoerus grypus. Linear regression of body weight gain on gross energy intake ( $\mathrm{kcal} \mathrm{kg}^{-1}$ of metabolic body weight) of pups for the first $29 \mathrm{~d}$ postpartum

adaptation to environmental pressures, primarily low air temperature. The positive correlation between increase in body weight and survival is well established. Mortality in British pups is highest among those that do not triple their birth weights by weaning (Coulson and Hickling, 1964). Most of the weight acquired in this short time is attributable to blubber. Mansfield (1977) showed that the sculp weight (blubber and skin combined) of Sable Island pups constitutes $50 \%$ of total body weight at $21 \mathrm{~d}$, compared with only $25 \% 2 \mathrm{~d}$ after birth. Baker et al. (1980) discussed pathological findings obtained from 68 pups found dead on several

Table 3. Proximate analysis of artificial formulas A and B, and whole, headless Atlantic herring

\begin{tabular}{|lccc|}
\hline \multirow{2}{*}{ Contents } & \multicolumn{4}{c}{ Formulas and fish, as-fed basis } \\
& $\mathrm{A}$ & $\mathrm{B}$ & Herring \\
\hline Gross energy, kcal g & & & \\
Crude protein, \% & 2.535 & 3.066 & 2.156 \\
Fat, \% & 3.91 & 4.63 & 18.35 \\
Ash, \% & 20.0 & 17.95 & 16.50 \\
Dry matter, \% & 0.23 & 0.54 & 4.30 \\
& 39.5 & 39.9 & 42.2 \\
\hline
\end{tabular}

British rookeries, Nearly all were grossly underweight, either from starvation or disease.

Canadian gray seals breed in January and February, or during the coldest time of the year. Most births occur in 2 locations: on sea ice in the Gulf of St. Lawrence, and on snow-covered beaches of Sable Island. In the Gulf of St. Lawrence air temperatures between 0 and $-20^{\circ} \mathrm{C}$ are typical, and wind velocity often is within the range of 2 to $5 \mathrm{~m} \mathrm{~s}^{-1}$ (Blix et al., 1979). From the moment of birth a seal may be exposed to a windchill of 0.9 to $2.1 \mathrm{~kW} \mathrm{~m}^{-2}$ (Blix et al., 1979). The birth coat (lanugo) offers little protection. It has poor insulative properties because it lacks an oily texture and is easily wetted (Ling and Button, 1975). Survival thus depends on how quickly a newborn seal can acquire a thick layer of subcutaneous fat.

Both pups experienced a mild, intermittent eye disorder characterized by redness around the entire circumference of the eyelid, and accompanied by a viscous exudate that crusted when dry. Hair loss occurred around the eyes. The condition was diagnosed as periocular alopecia. Signs were first recorded on Days 12 and 13 in the male and female, respectively. During that time both animals were examined for possible respiratory infections. This was done because Gallacher and Waters (1964) had demonstrated a relationship between 'septic' eyes and pneumonia in unweaned, wild gray seals in Britain. However, the respiratory tracts of these 2 pups were clinically normal. The condition was therefore treated topically by washing the eyes periodically with a warm saline or boric acid solution.

Both pups suffered from moderate diarrhea throughout the pre-weaning period. Reduction in frequency or degree was not affected by either Formula B or the force-feeding of raw fish. This loss of digestive and absorptive efficiency may have caused, in part, the subnormal growth rate and the high maintenance energy estimate. Formulas used to rear unweaned pin nipeds of other species typically induce enteritis and diarrhea (Poulter et al., 1965; Picken, 1975; Klös, 1979), and electrolyte imbalances, bowel stasis, and tissue dehydration (Poulter et al., 1965). Some of these factors may have been responsible for the chronic diarrhea and occasional behavioral signs of gastric distress that we observed.

According to Ling and Button (1975), molting of Canadian gray seal pups lasts slightly longer than $1 \mathrm{wk}$ and does not commence until after weaning. The suckling period lasts 14 to $15 \mathrm{~d}$ (Mansfield, 1977), compared with 16 to $21 \mathrm{~d}$ for British gray seals (Bonner, 1972). The pups described here started losing the lanugo on Day 12. The molting pattern followed the topographical sequence described in detail by Ling and Button (1975). The female finished molting on Day 


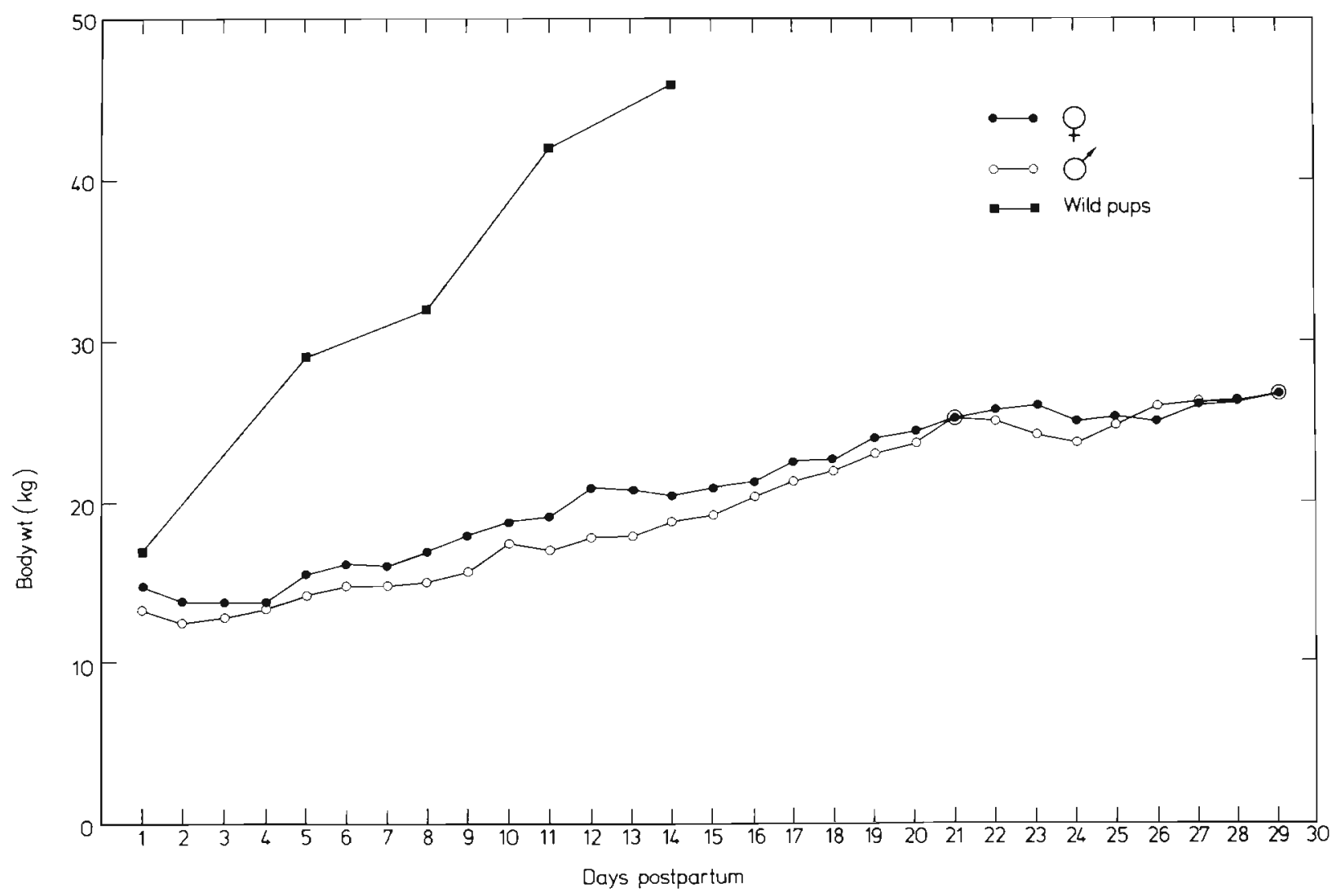

Fig. 6. Halichoerus grypus. Growth of the 2 captive-reared pups, compared with that of wild pups on Sable Island, Nova Scotia. The points on the curve for the wild pups are mean values for 8 individuals, plotted from data in Mansfield (1977)

23 and the male on Day 25. Thus the timing, duration, and pattern of molt were normal, compared with wild, Canadian gray seal pups, despite the abnormal environmental and nutritional conditions under which the animals were reared.

\section{CONCLUSIONS}

Unweaned pinnipeds reared artificially seldom gain weight in normal increments (Neugebauer, 1967; Mar. Mamm. Biol. Lab., 1970; Blix et al., 1973; Picken, 1975; Klös, 1979). This is convincing evidence that the rearing formulas used to date are nutritionally inadequate. The minimum energy requirement of 2775 to $3185 \mathrm{kcal}$ $\mathrm{d}^{-1}$ for suckling gray seals needs confirmation. An obvious error may have been introduced by studying pups with chronic diarrhea. Future reports on handrearing of pinniped pups should include a measure of digestible energy.

Our results suggest that environmental factors are more limiting than composition of the diet. The rapid deposition of blubber is less important when pups are hand-reared, provided that air temperature is main- hand-reared, provided that air temperature is maintained above freezing, the pelage is kept clean and dry, and wind chill is eliminated. The practice of keeping pups on wooden surfaces, rather than on concrete, appears to have merit as a means of reducing the unnecessary expenditure of calories. The thermal conductivity of wood and concrete are 0.062 and $0.54 \mathrm{cal}$ $\mathrm{s}^{-1} \mathrm{~cm}^{-1} \mathrm{C}^{\circ-1}$, respectively (Perry, 1950). Concrete thus conducts heat 8.7 times faster when both materials are at the same ambient temperature.

The length of time we allowed the pups to suckle (29 d) was chosen arbitrarily. In thin animals weaning is an added stress, because several days may elapse before fish is accepted as a substitute for formula. In pups that demonstrate linear growth, weaning probably can be started between 2 and 3 wk of age, or earlier than we report here.

Acknowledgements. We are grateful to Carrie Bourdeau for chemical analyses, Carol E. Bower and J. Lawrence Dunn for reviewing the manuscript. Paul Gaj for preparation of the figures, and Uwe Koehn and K. L. Knox for assistance in statistical analysis. Our appreciation also extends to staff members of Mystic Marinelife Aquarium who volunteered their time to help rear the pups. 


\section{LITERATURE CITED}

Amoroso, E. C., Mathews, J. H. (1951). The growth of the grey seal (Halichoerus grypus [Fabricius]) from birth to weaning. J. Anat. 85: 427-428

A.O.A.C. (Association of Official Agricultural Chemists) (1965). Official methods of analysis, 10th ed., Ass. Official Agri. Chem., Washington, D. C.

Baker, J. R., Anderson, S. S., Primer, J. H., Baird, A. (1980). The pathology of the grey seal (Halichoerus grypus). I. Publs Br. Vet. J. 136: 401-412

Blix, A. S., Grav, H. J., Ronald, K. (1979). Some aspects of temperature regulation in newborn harp seal pups. Am. J. Physiol. 236: R188-R197

Blix, A. S., Iversen, J., Pasche, A. (1973). On the feeding and health of young hooded seals (Cystophora cristata) and harp seals (Pagophilus groenlandicus) in captivity. Norw. J. Zool. 21: 55-58

Bonner, $W$ N. (1972). The grey seal and common seal in European waters. Oceanogr. mar. Biol. A. Rev. 10: 461-508

Burton, R. W., Anderson, S. S., Summers, C. F. (1975). Perinatal activities in the grey seal (Halichoerus grypus). J. Zool., Lond. 177: 197--201

Coulson, J. C., Hickling, C. (1964). The breeding biology of the grey seal, Halichoerus grypus, on the Farne Islands, Northumberland. J. Anim. Ecol. 33: 485-512

Gallacher, J. B., Waters, W. E. (1964). Pneumonia in grey seal pups at St. Kilda. Proc. zool. Soc. Lond. 142: 177-180

Geraci, J. R. (1977). Marine mammal care, Dept. Pathol., Ont. Vet. Coll., Univ. Guelph, Ont., Canada

Kates, M. (1972). Techniques of lipidology; isolation, analysis, and identification of lipids, Elsevier, New York

Kleiber, M. (1961). The fire of life, Wiley, New York

Klös, H.-G. (1979). Hand-rearing a southern elephant seal Mirounga leonina at West Berlin Zoo. Int. Zoo Yb. 19: 265-266

Lindemann, R. L. (1942). The trophic-dynamic aspect of ecology. Ecology 23: 399-418
Ling, J. K., Button, C. E. (1975). The skin and pelage of grey seal pups (Halichoerus grypus Fabricius); with a comparative study of foetal and neonatal moulting in the Pinnipedia. Rapp. P.-v. Réun. Cons. int. Explor. Mer 169: $112-132$

Mansfield, A. W. (1977). Growth and longevity of the grey seal Halichoerus grypus in eastern Canada. Int. Coun. Explor. Sea, Mar. Mamm. Comm. C. M./1977/N:6

Marine Mammal Biological Laboratory (1970). Special study: nutrition of pups. In: Fur seal investigations, 1967. U.S. Fish Wildlife Serv. Spec. Sci. Rpt.-Fish. 597: 23-25

N.R.C. (National Research Council) (1974). Nutrient requirements of dogs, No. 8. Nat. Acad. Sci., Washington, D. C.

N.R.C. (National Research Council) (1978). Nutrient requirements of laboratory animals, No. 10, 3rd ed., Nat. Acad. Sci., Washington, D. C.

Neugebauer, W. (1967). Breeding the southern elephant seal Mirounga leonina at Stuttgart Zoo. Int. Zoo Yb. 7: 152-154

Perry, H. H. (1950). Chemical engineers' handbook, 3rd ed., McGraw-Hill, New York

Picken, M. J. (1975). The rearing of, and some experiments with, a common seal, Phoca vitulina vitulina L. Rpt. Underwat. Ass. N. S. 1: $50-56$

Poulter, T. C., Pinney, T. C., Jennings, R. A., Hubbard, R. C. (1965). The rearing of Steller sea lions. In: Symposium on biological sonar and diving mammals, Proc. 2nd Ann. Conf. Biol. Sonar Div. Mamm., Menlo Park, Calif. pp. $49-62$

Stewart, R. E. A., Lavigne, D. M. (1980). Neonatal growth of northwest Atlantic harp seals, Pagophilus groenlandicus. J. Mammal. 61: 670-680

Van Dyke, D., Ridgway, S. H. (1977). Diets for marine mammals. In: Rechcigl, M. Jr. (ed). Handbook series in nutrition and food, Vol. II, Section G.: diets, culture media, and food supplements. CRC Press, Cleveland, pp. 595-598

Wooden, G. R, Knox, K. L., Wild, C. L. (1970). Energy metabolism in light horses. J. Anim. Sci. 30:544-548 